\title{
Phytoprotection
}

\section{Comparison of decision methods to initiate fungicide applications against cercospora blight of carrot}

\author{
V. Abraham, A.C. Kushalappa, O. Carisse, G. Bourgeois et P. Auclair
}

Volume 76, numéro 3, 1995

URI : https://id.erudit.org/iderudit/706088ar

DOI : https://doi.org/10.7202/706088ar

Aller au sommaire du numéro

Éditeur(s)

Société de protection des plantes du Québec (SPPQ)l

ISSN

0031-9511 (imprimé)

1710-1603 (numérique)

Découvrir la revue

\section{Citer cet article}

Abraham, V., Kushalappa, A., Carisse, O., Bourgeois, G. \& Auclair, P. (1995). Comparison of decision methods to initiate fungicide applications against cercospora blight of carrot. Phytoprotection, 76(3), 91-99.

https://doi.org/10.7202/706088ar
Résumé de l'article

Un modèle prévisionnel a été comparé, en 1991 et 1992, à d'autres méthodes pour son efficacité à déterminer le début des applications de fongicides utilisés pour lutter contre la brûlure cercosporéenne de la carotte, causée par le Cercospora carotae. Le premier traitement fongicide était appliqué lorsque : 1) les plants avaient atteint $15 \mathrm{~cm}$ de hauteur (méthode conventionnelle); 2) les feuilles intermédiaires de $50 \%$ des plants présentaient des symptômes (méthode du $50 \%$ d'incidence); 3) lorsque la valeur cumulative d'équivalence d'infection (CE) avait atteint 14 (méthode de prévision avec la valeur CIE =14); 4) lorsque la valeur CIE avait atteint 18 (méthode de prévision avec la valeur CIE = 18). Pour toutes les méthodes, les applications subséquentes de fongicides ont été faites aux 10 jours lorsqu'il n'y avait pas de pluie, et aux 7 jours en présence de pluie. Les valeurs CIE ont été calculées en fonction de la durée d'humectation du feuillage et de la température durant cette période, tout en tenant compte des périodes d'humidité élevée et d'interruptions des périodes d'humectation du feuillage, et étaient cumulatives depuis l'émergence des plants. Pour les méthodes avec prévision, que ce soit pour une valeur CIE de 14 ou de 18, aucune perte de rendement n'a été observée et moins de traitements ont été nécessaires comparativement à la méthode conventionnelle et à celle du 50 \% d'incidence. Dans une autre étude, les valeurs CIE ont été comparées aux pourcentages de champs qui avaient atteint des niveaux d'incidence de 50 , 80 et $100 \%$ afin d'établir les seuils de risque léger $(11<\mathrm{CIE}<15)$ et de risque élevé $(16<\mathrm{CIE}<20)$. Seulement $3 \%$ des champs avaient déjà atteint l'incidence de $50 \%$ lorsqu'une valeur CIE a atteint le seuil préconisé pour un risque faible et, $19 \%$ des champs, une incidence de $80 \%$ pour un risque élevé.
Ce document est protégé par la loi sur le droit d'auteur. L’utilisation des services d'Érudit (y compris la reproduction) est assujettie à sa politique d'utilisation que vous pouvez consulter en ligne.

https://apropos.erudit.org/fr/usagers/politique-dutilisation/ 


\title{
Comparison of decision methods to initiate fungicide applications against Cercospora blight of carrot
}

\author{
Varghese Abraham', Ajjamada C. Kushalappa1, Odile Carisse², \\ Gaétan Bourgeois ${ }^{2}$, and Patrick Auclair ${ }^{3}$
}

Received 95-02-22; accepted 96-03-02

In 1991 and 1992, two thresholds of a forecasting model were compared with two other decision methods for effectiveness in timing the first fungicide application against Cercospora blight of carrot induced by Cercospora carotae. The first fungicide application was made when : 1) the plants reached $15 \mathrm{~cm}$ in height (conventional method); 2) the intermediate (middle) leaves of $50 \%$ of the plants were diseased (50\% disease incidence threshold method); 3 ) the cumulative infection equivalence (CIE) was 14 (forecasting model $\mathrm{CIE} 14$ ); and 4) the $\mathrm{CIE}$ was 18 (forecasting model CIE 18). In all four treatments, subsequent applications of fungicide were made at 10-d intervals when there was no rain, and at 7-d intervals when there was rain. The CIE was calculated based on duration of leaf wetness and temperature during the wet period, corrected for high humidity and interrupted wet periods, and was cumulative starting at crop emergence. For thresholds of $\mathrm{CIE} 14$ and $\mathrm{CIE} 18$, no yield losses were observed and the total number of fungicide applications needed was lower compared to conventional and $50 \%$ disease incidence threshold methods. In a separate study, the $\mathrm{CIE}$ thresholds were related to the percentage of commercial fields that reached disease incidence thresholds of 50,80 and $100 \%$ to establish low risk (CIE 11-15) and high risk (CIE 16-20) thresholds. The forecasting of low and high risk $\mathrm{CIE}$ thresholds were too late for 3 and $19 \%$ of the commercial fields because those fields had more than 50 and $80 \%$ of the plants diseased, respectively.

\begin{abstract}
Abraham, V., A.C. Kushalappa, O. Carisse, G. Bourgeois et P. Auclair. 1995. Comparaison de méthodes de prise de décision pour commencer l'application de fongicides contre la brûlure cercosporéenne de la carotte. PHYTOPROTECTION 76 : 91-99.
\end{abstract}

Un modèle prévisionnel a été comparé, en 1991 et 1992, à d'autres méthodes pour son efficacité à déterminer le début des applications de fongicides utilisés pour lutter contre la brûlure cercosporéenne de la carotte, causée par le Cercospora carotae. Le premier traitement fongicide était appliqué lorsque : 1) les plants avaient atteint $15 \mathrm{~cm}$ de hauteur (méthode conventionnelle); 2) les feuilles intermédiaires de $50 \%$ des plants présentaient des symptômes (méthode du 50 \% d'incidence); 3) lorsque la valeur cumulative d'équivalence

$\overline{1 . \text { Department }}$ of Plant Science, Macdonald Campus of McGill University, Sainte-Anne-deBellevue, Quebec, Canada H9X 3V9

2. Agriculture and Agri-Food Canada, 430 Gouin Blvd., Saint-Jean-sur-Richelieu, Quebec, Canada J3B 3E6

3. Production en régie intégrée du sud de Montréal enr., 255, rang de l'Église, Sainte-Angèlede-Monnoir, Québec, Canada JOL 1P0 
d'infection (CIE) avait atteint 14 (méthode de prévision avec la valeur $\mathrm{CIE}=14$ ); 4) lorsque la valeur $\mathrm{CIE}$ avait atteint 18 (méthode de prévision avec la valeur $\mathrm{CIE}=18$ ). Pour toutes les méthodes, les applications subséquentes de fongicides ont été faites aux 10 jours lorsqu'il n'y avait pas de pluie, et aux 7 jours en présence de pluie. Les valeurs CIE ont été calculées en fonction de la durée d'humectation du feuillage et de la température durant cette période, tout en tenant compte des périodes d'humidité élevée et d'interruptions des périodes d'humectation du feuillage, et étaient cumulatives depuis l'émergence des plants. Pour les méthodes avec prévision, que ce soit pour une valeur CIE de 14 ou de 18, aucune perte de rendement n'a été observée et moins de traitements ont été nécessaires comparativement à la méthode conventionnelle et à celle du $50 \%$ d'incidence. Dans une autre étude, les valeurs CIE ont été comparées aux pourcentages de champs qui avaient atteint des niveaux d'incidence de 50,80 et $100 \%$ afin d'établir les seuils de risque léger $(11<\mathrm{CIE}<15)$ et de risque élevé $(16<\mathrm{CIE}<20)$. Seulement $3 \%$ des champs avaient déjà atteint l'incidence de $50 \%$ lorsqu'une valeur CIE a atteint le seuil préconisé pour un risque faible et, $19 \%$ des champs, une incidence de $80 \%$ pour un risque élevé.

\section{INTRODUCTION}

Carrot [Daucus carota L. ssp. sativus (Hoffm.) Arcang.] is an important vegetable crop in Canada and is produced on 3000 ha in the Quebec province. Cercospora blight induced by Cercospora carotae (Passerini) Solheim is known to attack all aerial parts of wild (Daucus spp.) and cultivated carrots (Hooker 1944). Leaves and petioles weakened by the disease can break off when gripped by mechanical harvesters resulting in unharvested carrots and significant yield losses, as in Alternaria blight caused by Alternaria dauci (Kühn) Groves \& Skolko (Gillespie and Sutton 1979). A survey conducted south west of Montréal showed the presence of blight in 91 and $99 \%$ of carrot fields with a maximum prevalence of 92 and $99 \%$ of plants diseased in 1988 and 1989, respectively (Arcelin and Kushalappa 1991). Initial symptoms are pinpoint necrotic spots that are later surrounded by a chlorotic border. The lesions become elongated on the edge of the leaf, circular on leaf blades and elliptical on petioles (Thomas 1943).

In Quebec, two methods are recommended to decide when to initiate fungicide spray programs to manage Cercospora blight. First, fungicide applications are initiated when plants reach $10-15 \mathrm{~cm}$ in height (CPVQ 1987); however, some sprays may not be needed when the weather is not conducive for disease development. In the second method, fungicide applications are initiated when disease incidence reaches thresholds of 80 or $100 \%$ of plants with at least one lesion on the intermediate (middle) leaf for early carrots and $50 \%$ for late carrots (Boivin and Sauriol 1984; Boivin et al. 1990). In this latter method, an integrated pest management program (IPM) developed for the muck soil regions of Montréal is used. The second method is available only to growers who participate in this IPM program. In both methods, subsequent sprays are made at $7-d$ intervals when there is rain and at $10-d$ intervals when there is no rain.

Epidemics of Cercospora blight are weather dependent. Initial inoculum of the pathogen seems to be always present in commercial fields (Hooker 1944; Thomas 1943). An infection model based on leaf wetness and temperature during the wet periods was developed (Carisse and Kushalappa 1990). For severe infection, the pathogen needs more than $24 \mathrm{~h}$ of leaf wetness at temperatures of $20-28^{\circ} \mathrm{C}$. A study on the effect of interrupted wet periods showed that infection was significantly reduced when the initial wet period was $<12 \mathrm{~h}$ and when the dry period interruption was $>12 \mathrm{~h}$ (Carisse and Kushalappa 1992). A forecasting model was developed using the data of Carisse and 
Kushalappa $(1990,1992)$ to decide when to apply the first fungicide treatment against Cercospora blight (Carisse et al. 1993). The model uses values for the cumulative infection equivalence $(\mathrm{CIE})$, from crop emergence until the current day. The values are derived from duration of leaf wetness and temperature during the wet period, corrected for high relative humidity and interrupted wet periods. A CIE of 14-16, which corresponds to a disease incidence threshold of $50 \%$, is considered to be the warning threshold, and a CIE of 18-20, which corresponds to a disease incidence threshold of $80 \%$, is considered to be the action threshold for fungicide application.

The objectives of this study were: i) to compare the effectiveness of the forecasting model for Cercospora blight of carrot with other methods to decide when to initiate fungicide applications; and ii) to evaluate the reliability of CIE thresholds to time initial fungicide applications under commercial conditions to manage Cercospora blight of carrot.

\section{MATERIALS AND METHODS}

\section{Field plots}

Experiments were conducted during the summers of 1991 and 1992 at the experimental farm of Agriculture and Agri-Food Canada in Sainte-Clotilde (lat. 45 ${ }^{\circ} 9^{\prime} \mathrm{N}$ long. $73^{\circ} 41^{\prime}$ W), located in a region with muck soils (organic humic mesisols) south of Montréal. Carrot cv. Sixpak II was sown on 3 June 1991 and 29 May 1992 in rows $60 \mathrm{~cm}$ apart and at a rate of 100 seeds $\mathrm{m}^{-1}$ (to obtain $70-75$ plants $\mathrm{m}^{-1}$ ) using a high-precision mechanical seeder. Each plot contained 12 rows that were arranged perpendicular to the direction of the block. Both sowings were considered as late crops, to be harvested from late September to the end of the growing season.

Air temperature and relative humidity were measured in the carrot canopy using two sensors (Vaisala model HMP35A) and leaf wetness was measured using two grid sensors (model 237), each connected to a datalogger (model CR-10). The sensors and logger were from Campbell Scientific Canada Corp., Edmonton. The leaf wetness sensors were positioned at an angle of $45^{\circ}$, at mid-canopy and were moved up as the plants grew. The temperature and relative humidity sensors were positioned $1 \mathrm{~m}$ above the ground inside a Stevenson shelter. The microclimatic variables were measured at 1-min intervals, and averaged for each hour. The data were retrieved from the logger by audio cassette and transferred to a microcomputer.

\section{Disease assessment}

Disease severity was assessed at weekly intervals, starting when the first true leaf was fully expanded. Ten plants were sampled arbitrarily from the 10 rows at the centre of each plot. Disease severity on each fully opened leaf of the sample plants was estimated using the HorsfallBarratt scale (Horsfall and Barratt 1945) and standard area diagrams (Arcelin and Kushalappa, unpublished data). In addition, the presence of blight was noted on the intermediate (middle) leaves of 20 plants sampled in treatment 2 to determine a $50 \%$ disease incidence threshold. A plant was considered diseased when at least one lesion was present on an intermediate leaf.

\section{Forecasting model for spray initiation}

The forecasting model to time initial fungicide applications (Carisse 1992; Carisse et al. 1993) was modified in that a fixed rather than a range of cumulative infection equivalence (CIE), previously designated as cumulative blight severity value, threshold was used. The model was based on weather favouring infection and assumed that the initial inoculum, and conditions for sporulation and dissemination processes were always optimal. Fungicide applications were initiated when the CIE threshold of 14 or 18 was reached. The calculation of $\mathrm{CIE}$ included the following steps : 1) The microclimatic observations served to determine the duration of leaf wetness, or the wet period since onset of leaf wetness until relative humidity declined to less than $90 \%$, and the temperature during the wet period. Two wet periods separated by a dry period of $\geq 12 \mathrm{~h}$ were considered as two wet periods. When wet periods were separated by dryness of $<12 h$, or by 
more than one dry period each $<6 \mathrm{~h}$ long, the wet period was considered continuous (the dry hours included in the wet periods). A maximum of $4 \mathrm{~d}$ was permitted for any given wet period. 2) Infection equivalence (IE) values for environment were calculated every day, based on the duration of wet periods and mean temperature during wet periods observed in the field during the preceding $4 \mathrm{~d}$, using a table previously established (Table 1). The IE of 0,1 , and 2 corresponded to low, medium and high infection, respectively. 3) The IE values for each day were cumulated, starting when the carrots were sown to derive the $\mathrm{CIE}$. $\mathrm{CIE}$ of 14 and 18 were used as action thresholds to initiate fungicide applications.

Field tests of the forecasting model Experimental plots were each $8 \mathrm{~m} \times 7.2 \mathrm{~m}$ (12 rows), arranged in a randomized complete block design with four treatments and three replications. The criteria for the initiation of fungicide applications for the four treatments were : 1) when the plants reached $15 \mathrm{~cm}$ in height (conventional method); 2) when the intermediate (middle) leaves of $50 \%$ of plants were diseased $(50 \%$ disease incidence threshold method); 3) when the CIE was 14 (forecasting model $\mathrm{CIE} \mathrm{14);} \mathrm{and} \mathrm{4)} \mathrm{when}$ the $\mathrm{CIE}$ was 18 (forecasting model $\mathrm{CIE}$ 18). In all four treatments, the subsequent fungicide applications were made at 10-d intervals when there was no rain and at 7-d intervals when there was rain. The fungicide mancozeb (manganese ethylenebisdithiocarbamate) was applied at a rate of $2.4 \mathrm{~kg}$ a.i. ha-1 (CPVO 1987) through Dithane DG ${ }^{\circledast}$ (mancozeb 75\%, manganese $15 \%$ and zinc equivalent $2 \%$ ), using a tractor-mounted boom sprayer (Berthoud, model sp6b) equipped with hydraulic nozzles (\#D3).

Carrots were harvested using a mechanical harvester. Two 6-m rows in the middle of each plot were harvested. The leaves and adhering soil were removed and the carrots were weighed.

Estimates of disease severity data for the season were used to calculate the proportion of maximum (or relative) area under disease progress curve (PAUDPC) using DISPAR, a microcomputer program developed by Kushalappa and Carisse (1990). A Fisher's LSD test (Steel and

Table 1. Infection equivalence (IE) ${ }^{\text {a }}$ value obtained with combinations of temperature and duration of continuous surface wetness for Cercospora carotae on carrot

Wetness duration (h)

$\leq 24 \quad 24-30 \quad 31-36 \quad 37-43 \quad 44-48 \quad 49-54 \quad 55-60 \quad 61-66 \quad 67-78 \quad 79-84 \quad 85-96$

Temperature

$\left({ }^{\circ} \mathrm{C}\right) \quad$ Infection equivalence

\begin{tabular}{|c|c|c|c|c|c|c|c|c|c|c|c|}
\hline 16 & 0 & 0 & 0 & 0 & 0 & 0 & 0 & 0 & 0 & 0 & 1 \\
\hline 17 & 0 & 0 & 0 & 0 & 0 & 0 & 0 & 1 & 1 & 1 & 1 \\
\hline 18 & 0 & 0 & 0 & 0 & 1 & 1 & 1 & 1 & 2 & 2 & 2 \\
\hline 19 & 0 & 0 & 0 & 1 & 1 & 1 & 2 & 2 & 2 & 2 & 2 \\
\hline 20 & 0 & 0 & 1 & 1 & 2 & 2 & 2 & 2 & 2 & 2 & 2 \\
\hline $21-23$ & 0 & 1 & 1 & 2 & 2 & 2 & 2 & 2 & 2 & 2 & 2 \\
\hline $24-25$ & 0 & 1 & 2 & 2 & 2 & 2 & 2 & 2 & 2 & 2 & 2 \\
\hline $26-27$ & 0 & 1 & 1 & 2 & 2 & 2 & 2 & 2 & 2 & 2 & 2 \\
\hline 28 & 0 & 0 & 1 & 2 & 2 & 2 & 2 & 2 & 2 & 2 & 2 \\
\hline 29 & 0 & 0 & 1 & 1 & 2 & 2 & 2 & 2 & 2 & 2 & 2 \\
\hline 30 & 0 & 0 & 0 & 1 & 1 & 1 & 2 & 2 & 2 & 2 & 2 \\
\hline 31 & 0 & 0 & 0 & 0 & 0 & 1 & 1 & 1 & 1 & 2 & 2 \\
\hline 32 & 0 & 0 & 0 & 0 & 0 & 0 & 0 & 0 & 0 & 1 & 1 \\
\hline
\end{tabular}

a IE was calculated from the infection model to predict the proportion of maximum number of lesions (PML) as a function of duration of wetness and temperature (Carisse and Kushalappa 1990 ) by cluster analysis of the predicted values; the three clusters were : $P M L=0<P M L$ $\leq 0.15,0.15<\mathrm{PML} \leq 0.57,0.57<\mathrm{PML} \leq 1.0$ which corresponded to IE of 0,1 , and 2 , indicating low, moderate and high infection, respectively (Carisse 1992). 
Torrie 1980) at $P=0.05$ was used to compare means of PAUDPC and yield for different treatments (SAS Institute Inc. 1987).

\section{Commercial field data collection and calculation of CIE}

Disease incidence observations and thresholds of 50,80 and $100 \%$ disease incidence in 1987, 1990 and 1991 in commercial fields in Sherrington (lat. $45^{\circ} 10^{\prime}$ $\mathrm{N}$ long. $\left.73^{\circ} 31^{\prime} \mathrm{W}\right)$, Sainte-Clotilde and Napierville (lat. $45^{\circ} 11^{\prime} \mathrm{N}$ long. $73^{\circ} 24^{\prime} \mathrm{W}$ ) were obtained from PRISME (Production en régie intégrée du sud de Montréal enr.). The fields differed with respect to cultural practices, cultivars and emergence dates. Only data for late carrots (cotyledon stage after 31 May) were used since weather observations were unavailable for early carrots. Data were analyzed for 105, 33, and 17 fields in 1987, 1990, and 1991, respectively. Weather data obtained by means of electronic monitoring systems, at the experimental farm of Agriculture and Agri-Food Canada in Sainte-Clotilde were used to calculate CIE values. The fields were located within a $10-\mathrm{km}$ radius from the Sainte-Clotilde farm.

From the disease incidence data, the cumulative proportion of commercial fields that reached a disease incidence thresholds of 50,80 and $100 \%$ were estimated for different days after crop emergence. In order to evaluate the reliability of $\mathrm{CIE}$ thresholds to initiate spray programs, the cumulative proportion of fields at the three different disease incidence thresholds was related to the $\mathrm{CIE}$ values cumulated during the same interval of time.

\section{RESULTS}

\section{Forecasting model and disease severity}

Cercospora blight was present on carrots in all treatments in both years of the study. Disease severity, expressed as PAUDPC, was higher in the CIE 18 plots in which the fungicide was first applied $70 \mathrm{~d}$ after sowing as opposed to 44-65 $d$ for other treatments (Table 2). In 1991, disease severity was again highest in treated plots using $\mathrm{CIE} 18$, followed by those using $\mathrm{CIE}$ 14 and the disease incidence threshold method, and was lowest in the conventional method. The analysis of variance and LSD tests indicated that values of PAUDPC for carrots sprayed based on the disease incidence threshold method and $\mathrm{CIE} 14$ did not differ significantly, but were significantly lower than in CIE 18 and higher than in checks sprayed based

Table 2. Impact of four decision methods on the earliness of the first fungicide application, total number of applications and disease severity of Cercospora blight in carrot fields in 1991 and 1992

\begin{tabular}{lccc}
\hline $\begin{array}{l}\text { Decision } \\
\text { method }^{\mathrm{a}}\end{array}$ & $\begin{array}{c}\text { Disease } \\
\text { severity } \\
\text { (PAUDPC) }\end{array}$ & $\begin{array}{c}\text { Total no. of } \\
\text { fungicide applications } \\
\text { required }\end{array}$ & $\begin{array}{c}\text { First fungicide } \\
\text { application } \\
\text { (d from sowing) }\end{array}$ \\
\hline 1991 & $0.00983 \mathrm{a}$ & 6 & 44 \\
Conventional & $0.01357 \mathrm{~b}$ & 5 & 60 \\
$50 \%$ DIT & $0.01547 \mathrm{~b}$ & 4 & 65 \\
CIE 14 & $0.01977 \mathrm{c}$ & 3 & 70 \\
CIE 18 & & & 43 \\
1992 & $0.00907 \mathrm{a}$ & 6 & 57 \\
Conventional & $0.01497 \mathrm{~b}$ & 5 & 61 \\
$50 \%$ DIT & $0.02263 \mathrm{c}$ & 4 & 71 \\
CIE 14 & $0.03243 \mathrm{~d}$ & 3 & 4 \\
CIE 18 & & 5 & \\
\hline
\end{tabular}

a $50 \%$ DIT is $50 \%$ disease incidence threshold; CIE is the cumulative infection equivalence.

b PAUDPC is the proportion of maximum area under the disease progress curve; means with the same letters are not significantly different according to the LSD test $(P=0.05)$. 
on the conventional method. In 1992, trends in disease severity were similar to those of 1991, with CIE 18 having the highest disease severity and the conventional method having the lowest.

\section{Forecasting model and total number of sprays}

The total number of sprays applied in both years were $6,5,4$, and 3 in the conventional, disease incidence threshold, CIE 14 and CIE 18 methods, respectively. With the conventional method, the first fungicide application was made 44 and $43 \mathrm{~d}$ after sowing in 1991 and 1992, respectively. In the disease incidence threshold method, initial spray was applied 60 and $57 \mathrm{~d}$ after sowing in 1991 and 1992, respectively. For the CIE 14 method, sprays were started 65 and $61 \mathrm{~d}$ after sowing in 1991 and 1992, respectively. Using the CIE 18 method, sprays were delayed by 70 and $71 \mathrm{~d}$ from sowing in 1991 and 1992, respectively. The CIE value had only reached 7 and 3 in 1991 and 1992, respectively, when the first fungicide was applied based on the conventional method, whereas the CIE value had reached 13 in both years when the first fungicide was sprayed based on the disease incidence threshold method.

\section{Forecasting model and yield}

Crop yield varied from 5.66 to $5.96 \mathrm{~kg} \mathrm{~m}^{-2}$ and 6.41 to $6.95 \mathrm{~kg} \mathrm{~m}^{-2}$ in 1991 and 1992 , respectively, for different treatments. There was no significant difference in yield among treatments, in both years. However, disease severity (PAUDPC) varied significantly among treatments in both years (Table 2).

\section{CIE values and disease incidence thresholds in commercial fields}

The pattern of increase in CIE in carrot plots varied among years and the initial increase was faster in 1987 and 1990 than in 1991 (Fig. 1). In each year, initial wet periods were followed by a dry period of 13-19 d. Thus, the CIE values remained at $\leq 11$ for 43,27 and $48 \mathrm{~d}$ after sowing in 1987, 1990 and 1991, respectively. Then, values of $\mathrm{CIE}$ suddenly increased from 11 to 20 within $2 \mathrm{wk}$. The total number of days when conditions favored infection (CIE $\geq 1$ ) was 21, 28, and 14 during 1987, 1990 and 1991, respectively.
When the disease incidence thresholds of 50,80 or $100 \%$ were reached, the $\mathrm{CIE}$ values varied in different fields. For higher disease incidence thresholds the CIE values were also higher (Fig. 2). The $50 \%$ disease incidence threshold was reached only in $3 \%$ of the commercial fields monitored at $\mathrm{CIE}<11$, while the threshold was reached in $20 \%$ of fields when $\mathrm{CIE}$ value was 11 . Since the $\mathrm{CIE}$ value remained at $\leq 11$ for $27-48 \mathrm{~d}$ in different years (Fig. 1), a value of 11 could be considered as a lower limit for not spraying. Recommendations of spray initiation at $\mathrm{CIE} 14$ and $\mathrm{CIE} 18$ would be too late, thus not very reliable, for about $25 \%$ and $56 \%$ of the fields, respectively. About $50 \%$ of the commercial fields reached a disease incidence threshold of $50 \%$ when the CIE value was 16 . Less than $10 \%$ of the fields reached $100 \%$ disease incidence threshold at CIE 15. The percentage of fields with 80 and $100 \%$ disease incidence thresholds increased rapidly at $\mathrm{CIE}>20$.

\section{DISCUSSION}

Timing the first fungicide application is an effective way of reducing the number of sprays required to manage Cercospora blight of carrot. Delaying fungicide application until a $50 \%$ disease incidence threshold is reached has saved up to $40 \%$ of the amount of fungicides used in Quebec, compared to the decision method based on conventional calendar spray (Boivin et al. 1990). In the present study, CIE 18 was the best threshold for timing the first fungicide application because fewer fungicide applications were required and there was no significant loss in yield, even though disease severity (PAUDPC) in this treatment was higher than in other treatments. At CIE 14, an average of one more application of fungicide was required than at $\mathrm{CIE} 18$. The greatest disease severity observed at harvest was only $6 \%$ and generally no yield loss occurs at this level of blight (Bourgeois and Kushalappa 1992). Significant yield loss was encountered at $20 \%$ disease severity in carrots with Alternaria blight since the diseased leaves snapped when gripped by harvesting machines, leaving carrots unharvested (Langenberg 1975). 


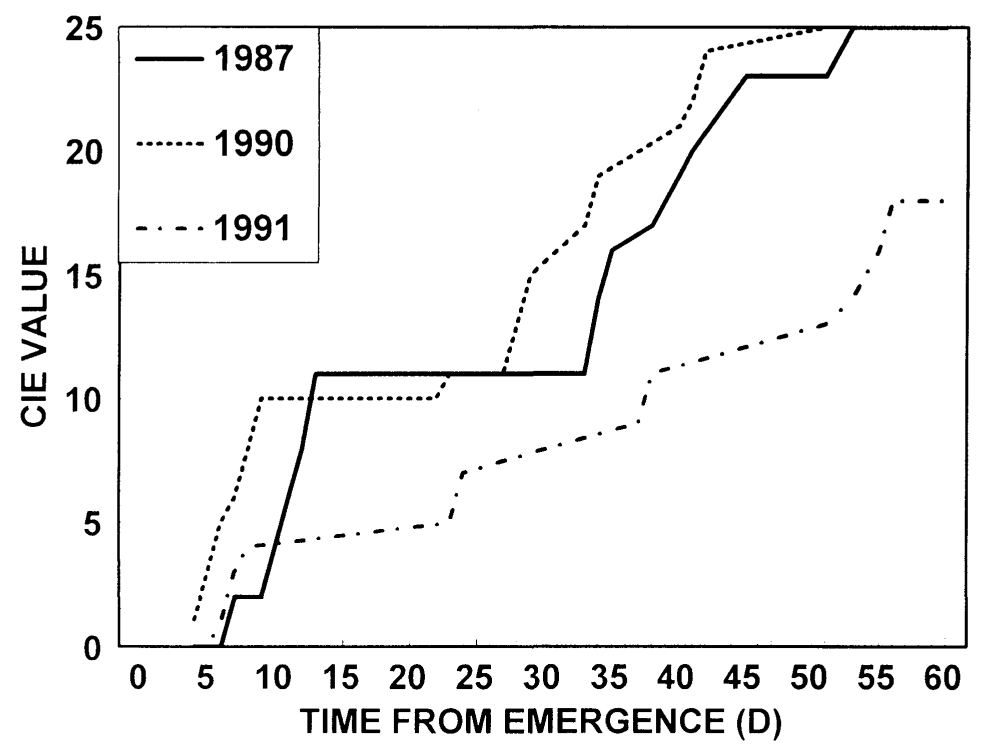

Figure 1. Patterns of increase of cumulative infection equivalence (CIE) values for Cercospora blight of carrot in 1987, 1990 and 1991. Values were calculated from duration of leaf wetness and ambient temperature during wet periods in carrot fields at Sainte-Clotilde. Day zero was 11 June.

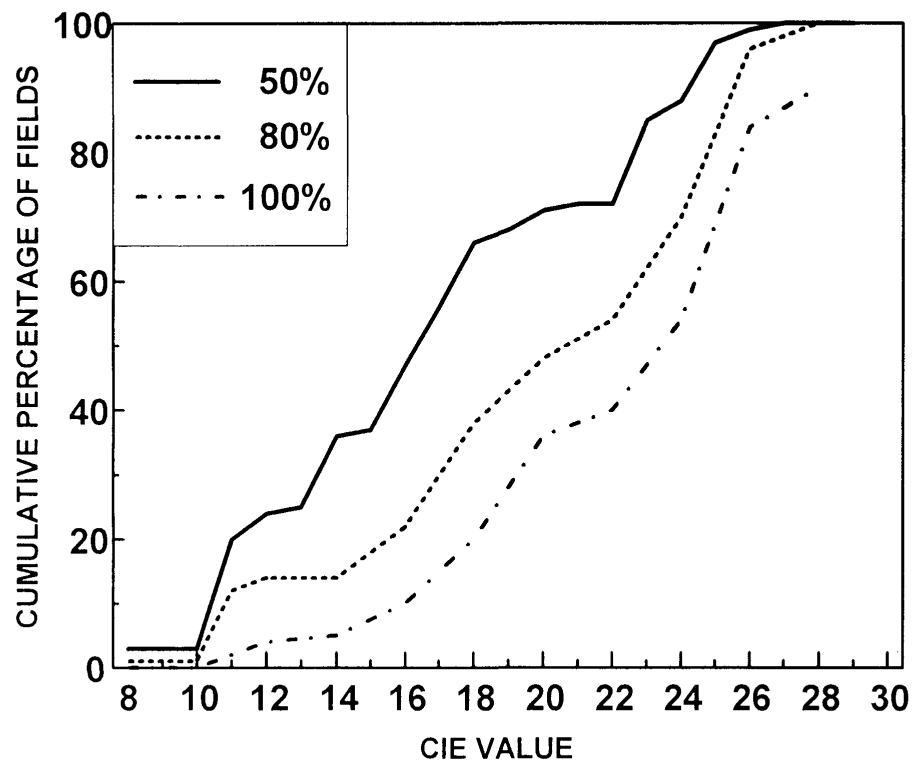

Figure 2. Cumulative increase in the percentage of 155 commercial carrot fields that reached disease incidence thresholds of 50,80 and $100 \%$, and its relation to increase in cumulative infection equivalence (CIE) values for weather variables during 1987, 1990 and 1991. The CIE values were calculated from the day of crop emergence using microclimatic data obtained from carrot fields at Sainte-Clotilde. 
Based on the performance of CIE thresholds 14 and 18 under experimental conditions and on the relation of $\mathrm{CIE}$ values to disease incidence thresholds of $50 \%$ (low risk) and $80-100 \%$ (high risk) under commercial field conditions, the following $\mathrm{CIE}$ thresholds are proposed to initiate applications of fungicide. Low risk forecast : 1) No fungicide is recommended when $\mathrm{CIE}<11 ; 2$ ) when $11<\mathrm{CIE}<15$, fungicide applications are initiated only when favourable weather conditions for infection are predicted (rain and temperature $>15^{\circ} \mathrm{C}$ ); 3) when $\mathrm{CIE} \geq 16$, apply fungicide immediately. High risk forecast : 1) No fungicide is recommended when $\mathrm{CIE}<16 ; 2$ ) when $16<\mathrm{CIE}<20$, fungicide applications are initiated only when favourable weather conditions for infection are predicted (rain and temperature $>15^{\circ} \mathrm{C}$ ); 3) when $\mathrm{CIE} \geq 21$, apply fungicide immediately. In both cases, subsequent fungicide applications are made at 10-d intervals when there is no rain and at 7-d intervals when rain occurs. The low risk recommendation would be too late for $3 \%$ of the growers, considering $50 \%$ disease incidence threshold, whereas the high risk recommendation would be too late for 19 and $9 \%$ of the growers considering disease incidence thresholds of 80 and $100 \%$, respectively. The low risk forecast can be recommended to growers in general. However, in the second condition, under circumstances that weather predicted as unfavorable turns out to be favorable, a low risk forecast could become high risk. A CIE value of 4 could be accumulated with only one long wet period. Nonetheless, even at $100 \%$ disease incidence level, only $1.2 \%$ leaf area was diseased (Boivin et al. 1990). Yield loss for Alternaria blight only occurred at disease severity of $>20 \%$ at harvest time (Gillespie and Sutton 1979). However, depending on the effectiveness of subsequent fungicide applications, a low initial disease incidence of $<2 \%$ can reach a disease severity $>20 \%$ at harvest time, thus causing significant yield loss. Effectiveness of fungicides depends upon variations in weather among years, amount of inoculum surviving in crop debris or the initial disease level, variation in cultural practices, and other factors.

The high risk threshold should be recommended with caution. The CIE value could increase rapidly from the action threshold of 16 to a value of 20 given one long wet period. Although there was no yield loss at $\mathrm{CIE}=18$, further delay in spraying until $\mathrm{CIE}=21$ could endanger the crop if the inoculum or the initial disease levels are already high.

The wide variation in CIE values observed in commercial fields could be explained by the different cultivars used, cultural practices and initial inoculum levels. Since the weather data was not obtained from each commercial field, the variation in weather and different sowing dates would also introduce more variation into the CIE values.

Calculations of CIE values require values for daily mean temperature, percent relative humidity and duration of leaf surface wetness. For this region of muck soil, though the hourly temperature and relative humidity data were available for some fields, the data on leaf wetness were not available. Consequently, some adjustments in the system are needed for use in commercial fields. Calculation of $\mathrm{CIE}$ was not accurate using only ambient temperature and relative humidity (Abraham, unpublished data). So, in the absence of leaf wetness data, models should be developed to predict duration of leaf wetness from operational weather data, canopy coverage and other related parameters, to improve the forecasting system and its implementation under commercial conditions.

The conventional method served here as a check. A control treatment without any fungicide application was not included because our objective was to find a method equivalent to using the $50 \%$ disease incidence threshold, which provided good control of blight under commercial conditions (Boivin et al. 1990). Also, an untreated control treatment would have increased interplot interference. Recommendations of CIE thresholds higher than those recommended here would require models predicting yield loss from Cercospora blight severity.

The CIE values could also be used to reduce the frequency of field visits by scouts in the $50 \%$ disease incidence threshold method. Disease monitoring is not necessary until CIE reaches 11, and 
more frequent samples may be collected when $11<\mathrm{CIE}<20$. Based on the 3-yr data, the time taken to reach $\mathrm{CIE}=20$ from $\mathrm{CIE}=11$ was 9-13 d. Although in our study the $\mathrm{CIE}$ thresholds were established based on commercial field data, the effectiveness of the thresholds of the forecasting system to time the first fungicide application should be validated over several years under commercial field conditions.

\section{ACKNOWLEDGMENTS}

This project was funded by the CanadaQuebec Subsidiary Agreement on Environmental Sustainability in Agriculture to Dr. A.C. Kushalappa and Dr. G. Bourgeois. This paper is a portion of the M.Sc. thesis of V. Abraham, submitted to the Faculty of Agricultural and Environmental Sciences of McGill University.

\section{REFERENCES}

Arcelin, R., and A.C. Kushalappa. 1991. A survey of carrot diseases on muck soils in the southwestern part of Quebec. Can. Plant Dis. Surv. 71 : 147-153.

Boivin, G., and P. Sauriol. 1984. Rentabilité du dépistage. Le Producteur agricole 7 : 4647.

Boivin, G., A.C. Kushalappa, and L. Brodeur. 1990. Spatial distribution and binomial sequential sampling plan for Cercospora carotae on carrots. Can. J. Plant Pathol. $12: 209-212$.

Bourgeois, G., and A.C. Kushalappa. 1992. Effet de la brûlure cercosporéenne sur le développement, la croissance et le rendement de la carotte. Phytoprotection 73 : 124-125.

Carisse, O. 1992. Effect of physical environment on Cercospora carotae and development of a model to predict Cercospora blight of carrot. McGill University, Ph.D. thesis, $189 \mathrm{pp}$.

Carisse, O., and A.C. Kushalappa. 1990. Development of an infection model based on temperature and duration of leaf wetness for Cercospora carotae on carrot. Phytopathology $80: 1233-1238$.
Carisse, O., and A.C. Kushalappa. 1992. Influence of interrupted wet periods, relative humidity and temperature on infection of carrots by Cercospora carotae. Phytopathology 82 : 602-606.

Carisse, O., A.C. Kushalappa, and G. Bourgeois. 1993. Development of a forecasting system to time the initial fungicide application to control Cercospora blight of carrot. $6^{\text {th }}$ Int. Cong. Plant Pathol., Montréal, 28 July to 6 August. p. 78 (Abstract).

CPVQ. 1987. Légumes : protection. Conseil des productions végétales du Québec, Ministère de l'Agriculture, des Pêcheries et de l'Alimentation du Québec. Agdex 250/605. $112 \mathrm{pp}$.

Gillespie, T.J., and J.C. Sutton. 1979. A predictive scheme for timing fungicide applications to control Alternaria leaf blight in carrots. Can. J. Plant Pathol. 1 : 95-99.

Hooker, W.J. 1944. Comparative studies of two carrot leaf diseases. Phytopathology 34 : 606-612.

Horsfall, J.G., and R.W. Barratt. 1945. An improved grading system for measuring plant diseases. Phytopathology $35: 655$.

Kushalappa, A.C., and O. Carisse. 1990. DISPAR: A microcomputer program to calculate foliar disease pest parameters in pest crop modelling. Pages 16-17 in P.S.Teng and J.E.Yuen (eds.), Proc. Workshop on Modelling Pest Crop Interactions. Univ. Hawaii, Honolulu.

Langenberg, W.J. 1975. Carrot leaf blight (Alternaria dauci) development in relation to environmental factors and fungicide applications. M.Sc. thesis, University of Guelph, Ontario, Canada, 119 pp.

SAS Institute Inc. 1987. SAS/STAT guide for personal computers. Version 6 edition. SAS Institute Inc., Cary, North Carolina. 1028 pp.

Steel, R.G.D., and J.H. Torrie. 1980. Principles and procedures of statistics, a biometrical approach. $2^{\text {nd }}$ ed. McGraw Hill Book Co., New York. 633 pp.

Thomas, R.H. 1943. Cercospora blight of carrots. Phytopathology 33 : 114-125. 